\title{
Pengenalan Karakter Plat Nomor Mobil Secara Real Time
}

\author{
Ikhwan Ruslianto*1, Agus Harjoko² \\ ${ }^{1}$ Mahasiswa Pasca Sarjana Jurusan Ilmu Komputer dan Elektronika, FMIPA UGM, \\ ${ }^{2}$ Staf pengajar Jurusan Ilmu Komputer dan Elektronika, FMIPA UGM, Yogyakarta \\ e-mail: *11ikhwanruslianto@gmail.com, ${ }^{2}$ aharjoko@ugm.ac.id
}

\begin{abstract}
Abstrak
Pengenalan plat nomor di Indonesia biasanya digunakan pada sistem parkir yang masih dilakukan secara manual, yaitu dengan mencatat karakter plat nomor oleh petugas jaga parkir. Padahal pengenalan plat nomor tidak hanya dilakukan untuk system perparkiran tetapi dapat digunakan untuk menemukan kendaraan yang melanggar peraturan lalu lintas dijalan raya secara real time, misalnya pelaku tabrak lari pada kecelakaan maupun kendaraan yang melanggar rambu-rambu lalu lintas.

Penelitian ini memberikan alternatif pengenalan karakter plat nomor mobil menggunakan metode connected component analysis dan matching sehingga dapat menyelesaikan permasalahan dengan background yang kompleks dan mobil yang bergerak dijalan raya.

Metode connected component analysis berhasil melakukan proses segmentasi plat dan segmentasi karakter dengan kondisi background yang kompleks secara tepat terhadap 67 sampel citra dengan tingkat keberhasilan 95,52\% untuk segmentasi plat dan 94,98\% untuk segmentasi karakter dan metode template matching berhasil melakukan proses pengenalan karakter secara akurat dengan tingkat keberhasilan 87,45\%.
\end{abstract}

Kata kunci-real time, connected component analysis, template matching

Indonesia's number plat recognition system are typically used in parking lots that are still done manually, by recording the license plate characters by parking guard. Though number plate recognition system is not only for parking but can be used to find vehicles that violate traffic rules highway street in real time, such as actors on the hit and run accident and the vehicles that violate traffic signs.

This study provides an alternative car number plate character recognition using connected component analysis and matching so as to solve problems with complex background and a moving car on the road.

Connected component analysis method successfully to the plates segmentation and character segmentation in complex background condition are appropriate to the 67 sample images with the success rate of $95.52 \%$ for the plate segmentation and $94.98 \%$ for plate character segmentation and template matching method successfully perform the character recognition process accurately with a success rate of $87.45 \%$.

Keywords - real time, connected component analysis, template matching 


\section{PENDAHULUAN}

Denelitian tentang pengenalan plat nomor kendaraan telah banyak dilakukan baik di Indonesia maupun di negara lain. Masing - masing dari penelitian tersebut memiliki permasalahan yang berbeda, baik dari segi fisik plat nomor maupun metode yang digunakan dalam proses pengenalan plat nomor. Plat nomor dari tiap negara memiliki model yang berbeda, baik dari warna maupun bentuk susunan karakternya, sehingga pengenalan plat nomor yang dilakukan di negara lain belum tentu bisa mengenali plat nomor yang ada di Indonesia. Sebagai contoh, karakter plat nomor Negara timur tengah yang menggunakan karakter huruf arab tentu saja akan berbeda dengan karakter plat nomor huruf di Indonesia, atau warna plat nomor Negara Korea Selatan yang berwarna hijau yang di Indonesia plat nomor tersebut berwarna hitam.

Pengenalan plat nomor di Indonesia biasanya digunakan pada sistem parkir yang masih dilakukan secara manual, yaitu dengan mencatat karakter plat nomor oleh petugas jaga parkir. Beberapa tahun terakhir banyak penelitian yang membahas tentang pengenalan plat nomor dengan berbagai jenis metode. Masing-masing metode tersebut memiliki kelebihan dan kekurangan. Penelitian sebelumnya tentang pengenalan plat nomor menggunakan metode $K$-Nearest Neighbor dalam proses pengenalan karakter dan metode thresholding untuk proses pencarian letak plat nomor kendaraan. Pencarian letak plat nomor dilakukan dengan mengubah citra menjadi citra biner (hitam putih) dan menghapus intensitas citra putih yang luasnya lebih besar dari nilai threshold, sehingga pada akhirnya yang dicropping hanya kandidat-kandidat obyek yang dianggap karakter dan masing-masing karakter akan dilakukan pengenalan menggunakan metode $K$ Nearest Neighbor dengan data latih yang telah dibuat sebelumnya [1]. Penelitian serupa tentang segmentasi karakter nomor menggunakan metode Run-Length Smearing Algorithm (RLSA). Smearing adalah suatu metode untuk mengekstraksi lokasi teks dalam suatu gambar. Cara kerja metode ini adalah dengan cara melakukan proses scanlines pada gambar secara vertikal dan horizontal sehingga dapat ditemukan lokasi plat pada citra beserta dengan karakter yang ada [2]. Kelemahan pada penelitian ini adalah kesulitan dalam melakukan segmentasi pada mobil yang memiliki warna cenderung mirip dengan warna plat nomor.

Penelitian ini menawarkan alternatif lain dalam pengenalan plat nomor mobil pada kondisi background yang kompleks, misalnya di jalan raya, sehingga pengenalan plat nomor tidak hanya dimanfaatkan untuk sistem perparkiran maupun sistem kontrol keluar masuk tol, akan tetapi dapat digunakan untuk menemukan kendaraan yang melanggar peraturan lalu lintas dijalan raya, misalnya pelaku tabrak lari pada kecelakaan maupun kendaraan yang melanggar rambu-rambu lalu lintas. Nantinya hasil dari pengenalan plat nomor tersebut dapat dijadikan sebagai bukti untuk menindak pengendara yang telah melakukan pelanggaran lalu lintas.

\section{METODE PENELITIAN}

\subsection{Pre-processing Citra}

Proses pre-processing citra dilakukan untuk mendapatkan citra yang kualitas lebih baik daripada citra sebelumnya dengan cara memanipulasi parameter-parameter citra, sehingga menghasilkan bentuk yang lebih cocok terhadap nilai-nilai piksel citra tersebut untuk proses selanjutnya.

\subsubsection{Derajat Keabuan (Grayscale).}

Citra grayscale atau citra beraras keabuan adalah citra yang hanya menggunakan warna pada tingkatan warna abu-abu. Warna abu-abu adalah satu satunya warna pada ruang RGB

IJCCS Vol. 7, No. 1, January $2013: 35-44$ 
dengan komponen merah, hijau, dan biru mempunyai intensitas yang sama. Nilai intensitas untuk tiap piksel pada citra beraras keabuan merupakan nilai tunggal dimana nilai intensitasnya berada pada interval 0-255, sedangkan pada citra berwarna perlu tiga nilai intensitas yang berada pada interval 0-255 untuk tiap pikselnya. Semakin mendekati nilai 255, maka derajat keabuan akan semakin terang.Pada dasarnya proses ini dilakukan dengan meratakan nilai piksel dari 3 nilai RGB menjadi 1 nilai. Tetapi karena ketiga warna pokok tersebut dianggap tidak seragam dalam hal kemampuan kontribusi pada kecerahan, ada yang berpendapat bahwa cara konversi yang lebih tepat adalah dengan menggunakan persamaan (1) [3] :

$$
Y=0.299 R+0.587 G+0.114 B
$$

dimana $\mathrm{Y}$ adalah nilai kecerahan suatu piksel pada citra abu-abu, dengan persentasi $29,9 \%$ dari warna merah $(R), 58,7 \%$ dari warna hijau $(G)$, dan $11,4 \%$ dari warna biru $(B)$.

\subsubsection{Contrast Stretching}

Contrast stretching adalah teknik yang digunakan untuk mendapatkan citra baru dengan kontras yang lebih baik daripada kontras dari citra asalnya [4]. Citra yang memiliki kontras rendah dapat terjadi karena kurangnya pencahayaan, kurangnya bidang dinamika dari sensor citra, atau kesalahan setting pembuka lensa pada saat pengambilan citra.

\subsubsection{Median Filter}

Median filter merupakan operasi menggantikan nilai piksel pada citra dengan nilai median atau nilai tengah dari piksel-piksel tetangganya dan pikes itu sendiri. Filter ini sangat efektif untuk menghilangkan noise jenis salt and pepper dan juga impulse sementara serta tetap mempertahankan detail citra karena tidak tergantung pada nilai-nilai yang umum dalam lingkungannya.

\subsubsection{Penajaman Citra}

Operasi penajaman citra bertujuan memperjelas tepi pada objek di dalam citra. Operasi penajaman dilakukan dengan melewatkan citra yang memiliki komponen yang berfrekuensi tinggi (misalnya tepi atau pinggiran objek) dan akan menurunkan komponen berfrekuensi rendah [5].

\subsection{Segmentasi Citra}

Segmentasi plat nomor mobil merupakan proses penting dalam sistem pengenalan plat nomor. Proses ini sangat menentukan keberhasilan dari hasil keluaran sistem pengenalan,karena dari citra input dengan background yang kompleks, sistem harus dapat menentukan dimana keberadaan atau letak plat nomor pada mobil.

\subsubsection{Deteksi Tepi}

Tepi (edge) merupakan himpunan piksel terhubung yang terletak pada boundary di antara dua region [4]. Tepi ditandai dengan adanya perubahan nilai intensitas yang mendadak atau besar dalam jarak yang singkat. Pelacakan tepi pada dasarnya merupakan operasi untuk menemukan perubahan intensitas yang berbeda dalam suatu citra. Tepi mencirikan batas-batas objek dan karena itu tepi berguna untuk proses segmentasi dan identifikasi objek didalam citra. Tujuan pendeteksian tepi adalah untuk meningkatkan penampakan garis batas suatu daerah atau objek didalam citra.

\subsubsection{Morfologi Citra}

Morfologi citra digital adalah suatu cara untuk menganalisa atau mendeskripsikan bentuk dari obyek digital [3]. Secara umum tujuan dari operasi morfologi pada citra biner adalah untuk memperbaiki bentuk obyek agar dapat menghasikan fitur-fitur yang lebih akurat ketika analisis dilakukan. Jadi operasi morfologi bukanlah operasi yang mempunyai tujuan analisis, melainkan suatu operasi yang bertujuan untuk memfasilitasi analisis yang akan dilakukan terhadap obyek tersebut. Operasi morfologi yang digunakan pada penelitian yaitu closing yang merupakan kombinasi operasi dilasi dan erosi yang dilakukan secara berurutan, 
dan opening yang merupakan kombinasi operasi erosi dan dilasi yang dilakukan secara berurutan.

\subsubsection{Pelabelan}

Pelabelan komponen dilakukan bila terdapat lebih dari satu objek yang akan dianalisis. Proses ini dilakukan dengan mencari komponen terkoneksi dalam suatu citra. Komponen terkoneksi merupakan bagian yang mewakili sebuah objek dalam citra yang mempunyai objek lebih dari satu. Pengecekan koneksitas dari suatu kumpulan piksel, dapat menandakan bahwa kumpulan piksel ini merupakan suatu objek tunggal, atau bukan yang dapat ditentukan dari terhubung atau tidaknya dengan kumpulan piksel lainnya di dalam citra biner.

\subsubsection{Thresholding}

Operasi binerisasi yaitu proses segmentasi dari sebuah citra grayscale dengan menghasilkan citra biner. Proses binerisasi ini memerlukan sebuah nilai threshold (T), proses menemukan nilai threshold dinamakan thresholding citra.

\subsubsection{Connected Component Analysis}

Proses ini merupakan tahapan filterisasi terhadap suatu obyek citra biner. Filterisasi dapat dilakukan dengan cara melakukan perhitungan untuk menentukan luasan area dari suatu obyek yang telah dilabeli. Suatu obyek dapat terdiri dari kumpulan obyek yang saling terkoneksi,oleh karena itu obyek tersebut dapat dihitung luasan area pembentuknya, sehingga dari perhitungan luasan tersebut dapat dijadikan filter untuk menghilangkan noise yang ada pada citra atau mengelompokkan obyek yang dibutuhkan dalam proses pengenalan.

\subsection{Pengenalan Karakter}

Proses pengenalan karakter dapat dilakukan dengan berbagai metode,pada penelitian ini metode yang digunakan untuk proses pengenalan karakter, yaitu menggunakan template matching. Input data citra pada proses pengenalan karakter yaitu citra hasil segmentasi masingmasing karakter yang dalam bentuk citra biner.

\subsubsection{Blocking Citra}

Proses blocking ialah proses membagi citra input menjadi beberapa blok dan dikenakan proses atau operasi yang sama pada saat yang bersamaan. Citra dibagi menjadi beberapa blok dengan ukuran $\mathrm{m} \times \mathrm{n}$ dan suatu operasi akan dilakukan pada setiap blok secara individual untuk menentukan nilai piksel dari blok berkaitan untuk kemudian ditampilkan sebagai output dalam satu variable tertentu.

\subsubsection{Reshape Citra}

Proses reshape citra bertujuan untuk merubah bentuk matriks menjadi lebih sederhana sehingga memudahkan dalam proses penghitungan nilai kemiripan masing-masing karakter citra uji.

\subsubsection{Template Matching}

Template matching adalah sebuah teknik dalam pengolahan citra digital untuk menemukan bagian-bagian kecil dari gambar yang cocok dengan template gambar. Sebuah pola ditempatkan di sebuah class dimana secara istilah 'paling mendekati' dengan matriks vektor yang sudah ditetapkan. Pendekatan paling sederhana adalah menggunakan Minimum Distance Classifier yaitu menghitung jarak Euclidian antara vektor pola yang tidak diketahui dengan setiap contoh vektor pola dan diambil jarak yang paling kecil.

\subsection{Metode dan Implementasi}

Pengenalan karakter plat nomor tidak hanya dilakukan sebagai sistem yang mempermudah dalam otomatisasi sistem perparkiran, akan tetapi dapat dilakukan sebagai sistem otomatisasi pencarian suatu plat nomor dijalan raya untuk menemukan pelaku pelanggaran rambu-rambu lalu lintas, maupun pelaku tabrak lari.

Perancangan alur sistem pengenalan ditunjukkan pada Gambar 1, bertujuan untuk mempermudah pemahaman terhadap jalannya penelitian pengenalan karakter pengenalan 
karakter. Diagram alir sistem pengenalan ini dibagi dua tahapan yaitu tahapan pelatihan dan tahapan pengenalan, tahapan pengenalan terdiri dari 4 proses yakni proses pre-processing, segmentasi plat, segmentasi dan pengenalan karakter.

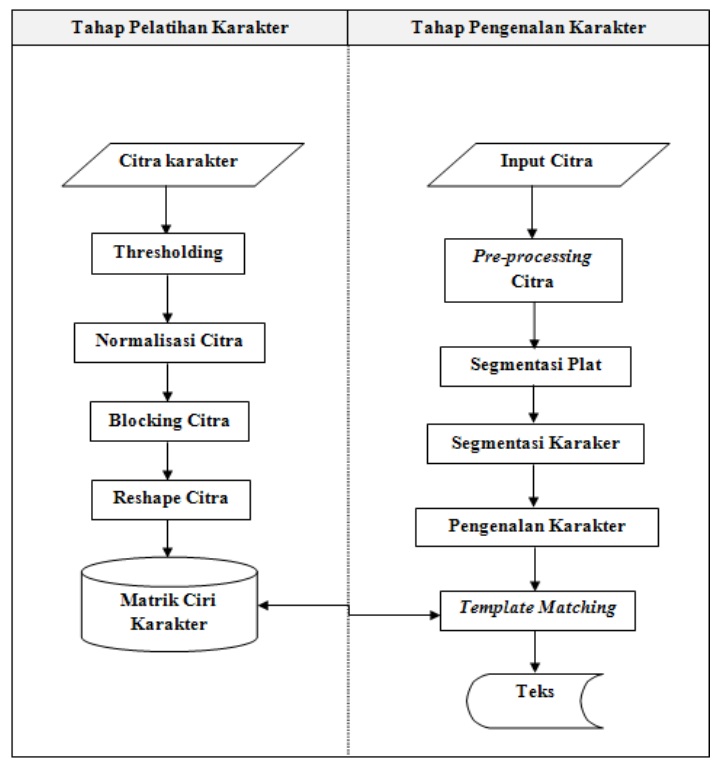

\section{Gambar 1 Rancangan Sistem Pengenalan Karakter Plat Nomor Mobil}

Tahap pelatihan karakter, dilakukan pada citra karakter yang didapat dari karakter plat nomor data citra yang proses akuisisi datanya sama dengan akuisisi data proses pengenalan, hanya saja citra karakter yang digunakan sebagai data pelatihan tidak digunakan sebagai citra uji. Masing-masing citra karakter akan diresize menjadi ukuran $21 \times 15$ piksel dan disimpan sebagai matriks ciri karakter. Sedangkan tahap pengenalan karakter terdiri dari 4 tahapan utama yaitu pre-processing citra, segmentasi plat, segmentasi karakter dan pengenalan karakter.

Tahapan pertama pada pengenalan karakter yaitu pre-processing citra, yang bertujuan untuk menghasilkan kualitas citra yang lebih baik dari citra sebelumnya. Gambar 2 menunjukkan diagram alir proses pre-processing citra.

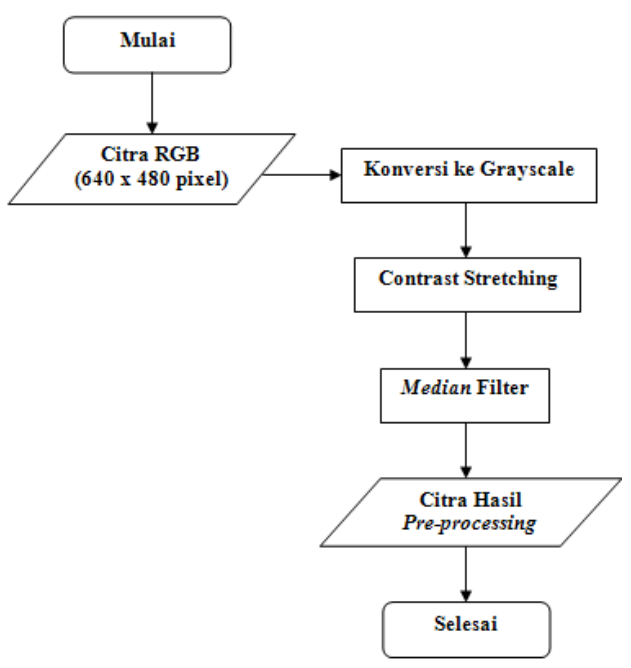

Gambar 2 Proses Pre-processing Citra

Akuisisi citra dilakukan dengan mengcapture citra plat mobil dijalan raya dengan background yang kompleks dan posisi mobil berpindah-pindah dengan resolusi citra 640x480 piksel. Proses pre-processing dilakukan dengan tujuan untuk mendapatkan kualitas citra yang 
lebih baik dari citra aslinya. Noise yang ada pada citra dapat dihilangkan dengan metode median filter sehingga dapat mempengaruhi untuk proses pengenalan selanjutnya. Hasil citra tahapan pre-processing citra ditunjukan pada Gambar 3.

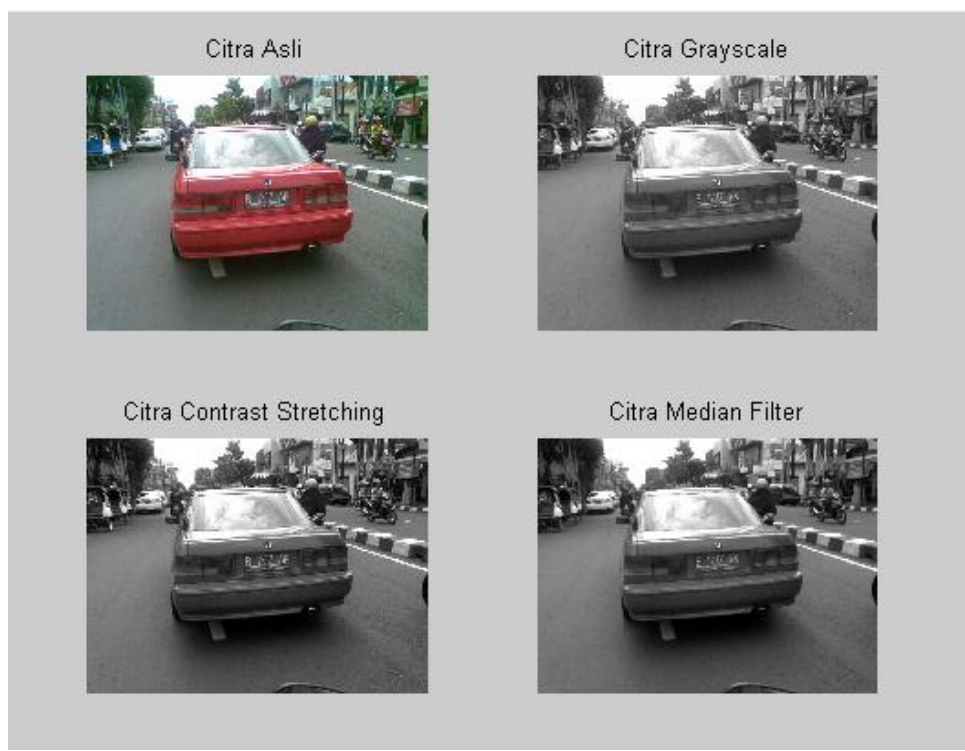

Gambar 3 Hasil proses Pre-processing Citra

Citra hasil pre-processing akan digunakan sebagai input data untuk proses segmentasi plat. Diagram alir segmentasi plat nomor ditunjukkan pada Gambar 4.

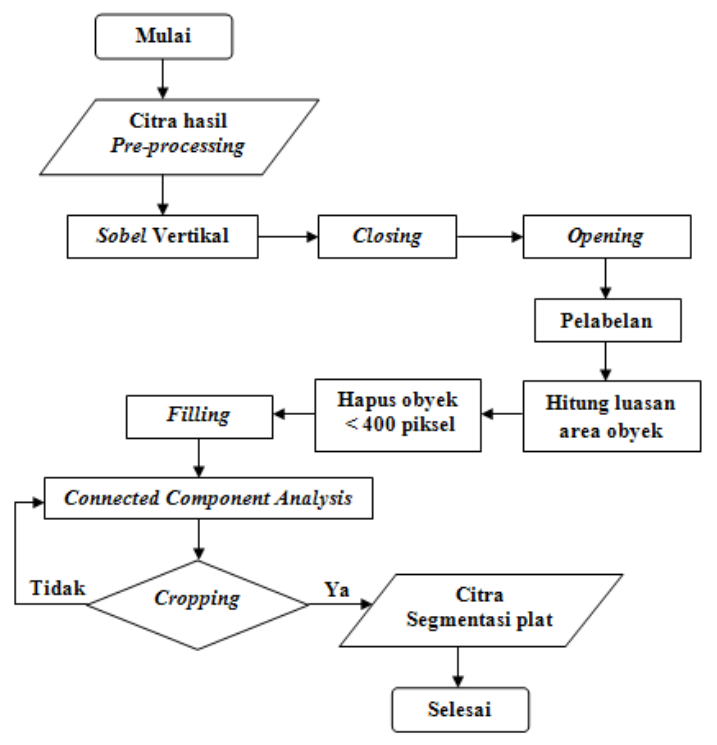

Gambar 4 Proses Segmentasi Plat

Proses segmentasi plat dilakukan dengan mengambil ekstraksi ciri dari plat nomor pada citra. Ekstraksi ciri dilakukan dengan metode deteksi tepi sobel operator vertikal, sehingga tepian dari obyek plat nomor dapat terlihat dengan jelas. Kemudian titik-titik piksel atau garis tepian tersebut disambung antara sesama piksel terdekat sehingga membentuk sekumpulan piksel yang merupakan kandidat obyek plat dengan operasi morfologi closing dan opening.

Langkah berikutnya, akan dilakukan proses analisis terhadap obyek citra seperti menghitung luasan, tinggi, maupun lebar obye, dari kandidat-kandidat obyek yang ada akan dilakukan filterisasi aturan yang mewakili sebuah plat nomor dengan metode connected 
component analysis, sehingga obyek yang tidak memenuhi aturan akan dihapus atau dihilangkan dari citra yang diproses. Kandidat obyek yang memenuhi aturan tersebut akan dicropping yang merupakan citra hasil segmentasi plat nomor. Hasil citra segmentasi plat akan dijadikan sebagai input data dalam segmentasi karakter dan pengenalan karakter

Proses berikutnya akan dilanjutkan pada proses segmentasi karakter yang diagram alirnya ditunjukkan pada Gambar 5.

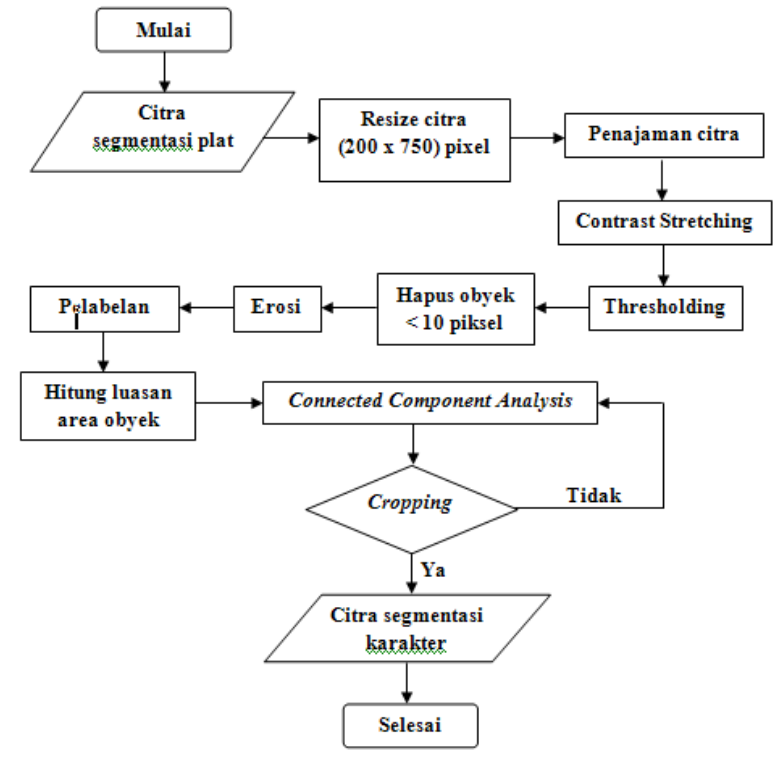

Gambar 5 Proses Segmentasi Karakter

Sama halnya pada proses segmentasi plat nomor,proses segmentasi karakter juga dilakukan dengan metode component connected analysis. Masing-masing karakter akan dipisahkan dengan melakukan filterisasi aturan yang merupakan suatu karakter, sehingga obyek kandidat yang tidak memenuhi aturan karakter secara keseluruhan, maka bukan dianggap karakter dan akan dihapus dari citra,sedangkan yang memenuhi akan dicropping dan dipisahkan dari latar belakang obyeknya serta akan dikenali masing-masing karakternya dengan metode template matching. Gambar 6 merupakan diagram alir pengenalan karakter menggunakan metode template matching.

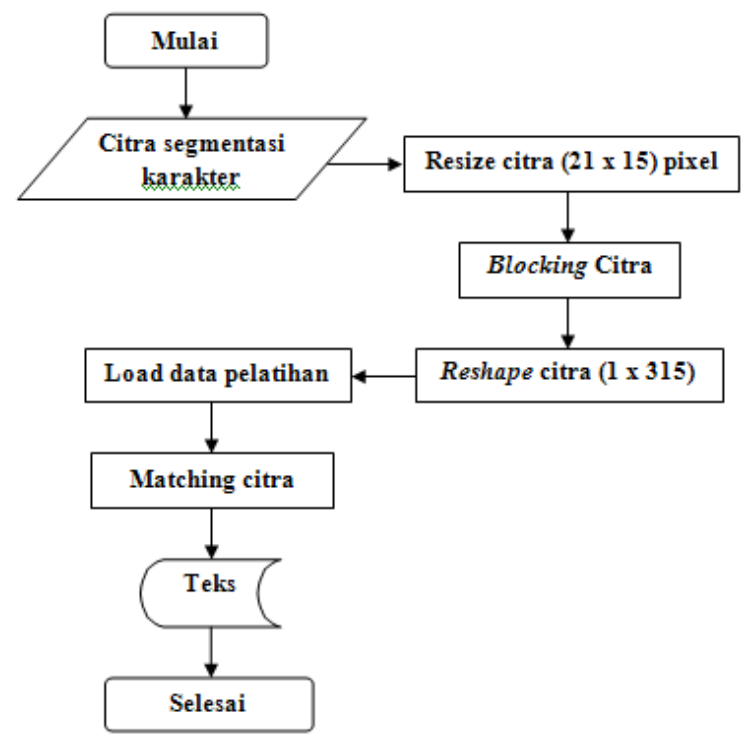

Gambar 6 Proses Pengenalan Karakter 
Gambar 7 merupakan salah satu proses pengenalan yang berhasil dilakukan,mulai dari proses segmentasi plat, segmentasi karakter sampai pengenalan karakter

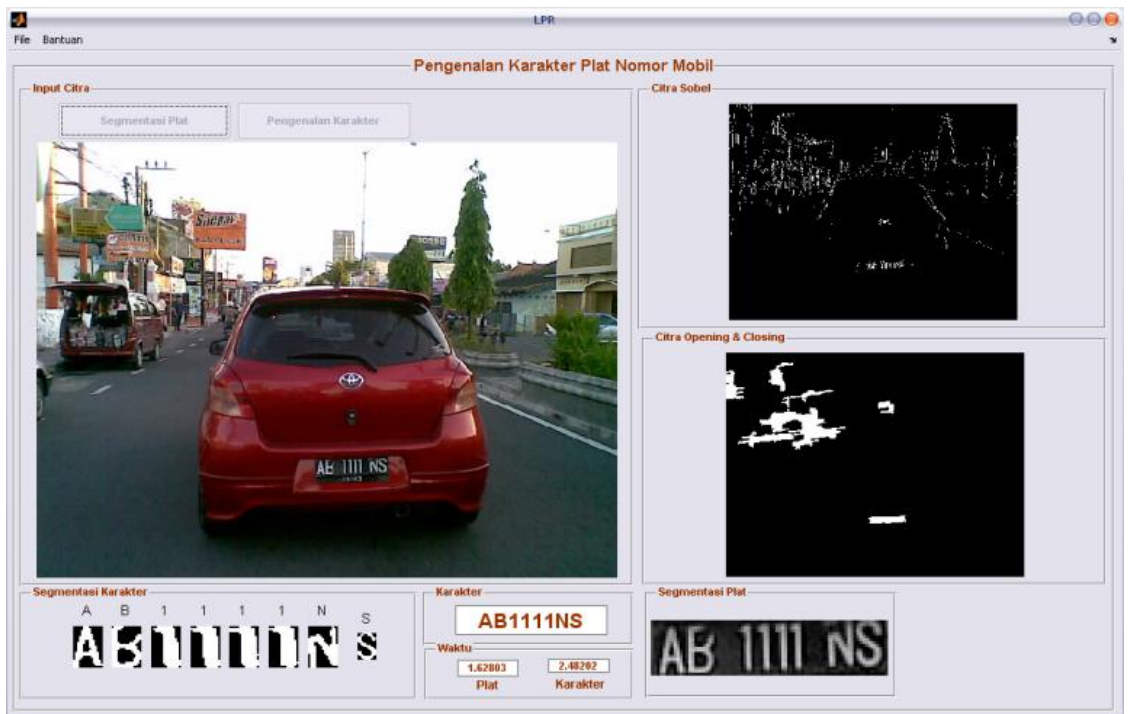

Gambar 7 Hasil Sistem Pengenalan Karakter Plat Nomor

\section{HASIL DAN PEMBAHASAN}

Pengujian sistem ini dilakukan untuk mengetahui tingkat keberhasilan dalam proses segmentasi plat, segmentasi karakter dan pengenalan karakter. Pengujian dilakukan terhadap 67 sampel citra yang diambil di jalan raya pada kondisi pagi, siang dan sore hari. Proses pengujian dilakukan pada masing-masing tahapan pengenalan karakter plat nomor, pengujian segmentasi plat ditunjukkan pada Tabel 1 .

Tabel 1 Hasil Pengujian Segmentasi Plat

\begin{tabular}{|c|c|c|l|}
\hline $\begin{array}{c}\text { Jumlah } \\
\text { Sampel }\end{array}$ & $\begin{array}{c}\text { Segmentasi } \\
\text { Plat Berhasil }\end{array}$ & $\begin{array}{c}\text { Segmentasi } \\
\text { Plat Gagal }\end{array}$ & \multicolumn{1}{c|}{ Keterangan } \\
\hline 67 citra & 64 citra & 3 citra & $\begin{array}{l}\text { Kegagalan proses segmentasi plat disebabkan } \\
\text { faktor cahaya yang berlebihan, karakter plat } \\
\text { yang kabur dan warna karakter plat yang } \\
\text { bukan putih }\end{array}$ \\
\hline Prosentase & $\mathbf{9 5 , 5 2 \%}$ & $\mathbf{4 , 4 8 \%}$ & \\
\hline
\end{tabular}

Pengujian segmentasi karakter juga dilakukan terhadap 67 sampel citra yang sama. Hasil dari pengujian proses segmentasi karakter ditunjukkan pada Tabel 2.

Tabel 2 Hasil Pengujian Segmentasi Karakter

\begin{tabular}{|c|c|c|l|}
\hline $\begin{array}{c}\text { Jumlah } \\
\text { Karakter }\end{array}$ & $\begin{array}{c}\text { Karakter } \\
\text { Berhasil } \\
\text { diekstrak }\end{array}$ & $\begin{array}{c}\text { Karakter } \\
\text { Gagal } \\
\text { diekstrak }\end{array}$ & \multicolumn{1}{|c|}{ Keterangan } \\
\hline $\begin{array}{c}518 \\
\text { karakter }\end{array}$ & $\begin{array}{c}492 \\
\text { karakter }\end{array}$ & 26 karakter & $\begin{array}{l}\text { Kegagalan segmentasi disebabkan adanya } \\
\text { karakter yang saling terhubung, pantulan cahaya } \\
\text { matahari dan adanya bentuk karakter yang } \\
\text { dimodifikasi. }\end{array}$ \\
\hline Prosentase & $\mathbf{9 4 , 9 8 \%}$ & $\mathbf{5 , 0 2 \%}$ & \\
\hline
\end{tabular}

IJCCS Vol. 7, No. 1, January $2013: 35-44$ 
Pengujian pengenalan karakter juga dilakukan terhadap 67 sampel citra yang sama. Hasil dari pengujian proses pengenalan karakter ditunjukkan pada Tabel 3.

Tabel 3 Hasil Pengujian Pengenalan Karakter

\begin{tabular}{|c|c|c|l|}
\hline $\begin{array}{c}\text { Jumlah } \\
\text { Karakter }\end{array}$ & $\begin{array}{c}\text { Berhasil } \\
\text { dikenali }\end{array}$ & $\begin{array}{c}\text { Gagal } \\
\text { dikenali }\end{array}$ & \multicolumn{1}{|c|}{ Keterangan } \\
\hline $\begin{array}{c}518 \\
\text { karakter }\end{array}$ & $\begin{array}{c}453 \\
\text { karakter }\end{array}$ & $\begin{array}{c}65 \\
\text { karakter }\end{array}$ & $\begin{array}{l}\text { Kegagalan pengenalan disebabkan adanya kemiripan } \\
\text { karakter satu sama lain, seperti B dan 8, 2 dan Z, 1 } \\
\text { dan I, D dan 0, A dan 4. } \\
\text { Ketidaksempurnaan dalam segmentasi karakter dapat } \\
\text { menyebabkan karakter terpotong yang dapat } \\
\text { mengubah persepsi pengenalan karakter. }\end{array}$ \\
\hline
\end{tabular}

Beberapa faktor penting yang mempengaruhi keberhasilan dalam proses pengenalan karakter plat nomor yaitu belum adanya ketegasan dalam standarisasi plat nomor di Indonesia, sehingga memungkinkan plat nomor dapat mengalami modifikasi oleh pemilik mobil. Cahaya matahari yang berlebihan juga dapat mempengaruhi keakuratan dalam segmentasi karakter

\section{KESIMPULAN}

1. Metode connected component analysis berhasil melakukan proses segmentasi plat dan segmentasi karakter dengan kondisi background yang kompleks cukup tepat terhadap 67 sampel citra dengan tingkat keberhasilan 95,52\% untuk segmentasi plat dan 94,98\% untuk segmentasi karakter.

2. Metode template matching berhasil melakukan proses pengenalan karakter cukup akurat hasil dari segmentasi plat dan segmentasi karakter terhadap 67 sampel citra dengan tingkat keberhasilan $87,45 \%$.

3. Beberapa penyebab kegagalan dalam proses segmentasi plat nomor yaitu adanya pantulan cahaya matahari yang mengenai plat nomor, karakter dari plat nomor yang kabur atau sudah memudar dan warna karakter plat yang tidak berwarna putih.

\section{SARAN}

1. Adanya proses pre-processing terhadap citra yang memiliki cahaya terlalu terang maupun terlalu gelap sehingga kualitas citra menjadi lebih baik dari sebelumnya.

2. Program dapat mensegmentasi karakter yang saling terhubung satu sama lain, maupun yang terhubung dengan garis tengah pada plat nomor.

3. Adanya pengembangan metode segmentasi plat sehingga dapat mengenali semua jenis warna plat yang ada di Indonesia.

4. Sistem dibangun dengan mengkoneksikan pada database suatu server, sehingga plat nomor yang dikenali dapat disimpan sebagai suatu data dokumentasi bagi pihak Kepolisian 


\section{DAFTAR PUSTAKA}

[1] Iswanto, N., Usman, K., Novamizanti, L., 2010, Desain dan Implementasi Color Code untuk Verifikasi Nomor Kendaraan Bermotor pada Sistem Parkir.

[2] Liliana, Budhi, G.S., Hendra, 2010, Segmentasi Plat Nomor Kendaraan Dengan Menggunakan Metode Run-Length Smearing Algorithm (RLSA).

[3] Ahmad U., 2005, Pengolahan Citra Digital dan Teknik Pemogramannya, Graha Ilmu, Yogyakarta

[4] Gonzalez, C.R. and Wood, E.R., 2008, Digital Image Processing, Third Edition, PrenticeHall inc., Upper Saddle River, New Jersey

[5] Mandala, R., 2009, Perbaikan Kualitas Citra 2, http://gunsbrotherhood.files.wordpress.com/2012/02/perbaikan-kualitas-citra2.pdf, diakses 14 Mei 2012 